\title{
Impact of Emotional Intelligence on People Orientation of Servant Leaders: Capacitive Study of Gender an Evidence from Telecom Sector of Pakistan
}

\section{Shamshad I*}

Department of Economics, Federal Urdu University of Arts, Science and Technology, Pakistan

\begin{abstract}
Objective of this study was to investigate the relationship between people orientation of servant leadership and emotional intelligence, and compare how much this relationship is different to male and female. Globally, organizations use leadership as key factor to motivate and improve work environment while emotional intelligence to test and assist their employees' psychological needs. This study will provide the detail impact of emotional intelligence on servant leadership and its facets of people orientation separately and will help organization to fix or improve health of variable under discussion. Survey and structural modeling both techniques were used to test empirical relationship between variables based upon 50 responses. Questionnaire (standardized) were employed to calculate two constructs. High validity and reliability were found for both scales and inter-item correlation was also established. Results shows that there is positive and significant relationship present between emotional intelligence and servant leadership, it was also found that emotional intelligence effect more on female servant leadership facets as compare to men. As practical implementation organizations must conduct trainings of emotional intelligence for employees and especially for their leaders to improve performance of number of variables affect by servant leadership at workplace.
\end{abstract}

Keywords: Leadership; Emotional intelligence; Servant leadership; People orientation; Trait theory

\section{Introduction}

Though there are number and numbers of definitions of leadership from each prospective but which is more suitable to that specific research is depend upon the context and environment in which study is been executed [1]. In all type of organizations, leadership is always present as defined, "a process through which an individual influence, motivate, administer, communicate with others in order to get desired outcomes" [2] leader is the person who use to perform these phenomenon, who generally use to collect the efforts of all the workers to get success.

Leader has to work in such a way that employee's feel a real zeal and enthusiasm to work for that specific organization and feel appreciated and empowered in their specific domain. Shatali [1] said that leader is like a captain, whose very presence is a bravery, comfort and initiative for other soldiers. Leader is like a god father whose presence and support provide s motivation and strength to workforce. All managers are not leaders like all basis are not alkalis in chemistry. Being a servant leader one has to rule on heart not only in organized environment [3]. Leader must be farsighted, creative, initiator, visionary and he/ she achieve subordinates' obedience by will not by force because of his leadership and sovereignty. Also found that "Leadership can be defined as influence, that is, the area or process of influencing people so that they will strive willingly and enthusiastically towards achievement of group goals".

One of the most studied and growing area of both core psychology and organizational psychology is emotional intelligence [4]. Salovey et al. [4] said that "the ability to monitor one's own and others' feelings and emotions, to discriminate among them, and to use this information to guide one's thinking and actions is emotional intelligence". It is examined and proved that each individual has different abilities with respect to emptions of themselves or of others regarding recognizing, understanding, perceiving, evaluating and reacting towards them, that's why reactions of individual are different and varies for situation to situation and even in same situation one individual act in completely different way from another $[5,6]$.

Now-a-days the labor and the workforce is highly empowered and educated as compare to previous decades. As with the passage of time, dynamics of work environment changed with technology and innovation though the working style and motivational and persuasion techniques been used by leaders. Now the job of leader is not only consult or co-operate but to manage the motivation, and minds of employees. Many new dimension like involvement, authority, freedom, team working spirit, support and much more are new era dynamics expected by each leader in each filed.

Study of emotional intelligence at workplace is relatively new when it comes to its interaction with servant leadership or even as individual variable and will add knowledge to very few local studies. This research is a contribution to the need of Pakistan to identify the main competencies required in servant leadership roles with emotional intelligence and how these competencies may lead to successful management of working teams.

Purpose if this study is to find out and estimate the relationship between previously said variables, and further in-depth effect of emotional intelligence on people orientation and how it is different for each gender. Model mentioned below depict the interrelationship between variable and dimensions as proposed. Accordingly, this study

*Corresponding author: Shamshad I, Department of Economics, Federal Urdu University of Arts, Science and Technology, Pakistan, Tel: +922199244141; E-mail: iqrashamshad@live.com

Received October 03, 2016; Accepted December 12, 2016; Published December 16,2016

Citation: Shamshad I (2016) Impact of Emotional Intelligence on People Orientation of Servant Leaders: Capacitive Study of Gender an Evidence from Telecom Sector of Pakistan. J Glob Econ 4: 228. doi: 10.4172/2375-4389.1000228

Copyright: () 2016 Shamshad I. This is an open-access article distributed under the terms of the Creative Commons Attribution License, which permits unrestricted use, distribution, and reproduction in any medium, provided the original author and source are credited. 
is being performed to analyze the relationship of emotional intelligence and people orientation of servant leadership in workplace. The empirical proof is used to test linkage between Emotional Intelligence and servant leadership.

\section{Literature Review}

\section{Leadership}

Leadership if not only influencing others but more about team working but relationship building, creating harmony and affection, role differentiation, enhancing skills of workers and creating a feasible and approving environment for people to work [7] with efficiency and effectiveness with devotion and avidity. The best understood and accepted definition of leadership by most of scholars is "as the nature of the influencing process - and its resultant outcomes - that occurs between a leader and followers and how this influencing process is explained [8]. More than century long and detailed studies of leadership come the conclusion that specific theories of leadership has contributed much toward s understanding and clarity of core idea of leadership.

Study perform in the University of Michigan about leader's behavior, by Fielder et al. [9] about situation, Leader-Member Exchange Theory by [10]. House et al. [11] explained that how leaders inspire and influence their followers and call it "New Leadership". These "new" theories explored the charisma and vision of followers to get their goals at highest. In all discussion perhaps most advocated and widely accepted theory was trait theory also called great man perspective basically shaped by historians, who noted that "the history of the world was the biography of great men [12].

The empirical results of trait association with leader is that these characteristics separates the successful leads and unsuccessful leaders and got a history in psychological studies [13]. During mids of $20^{\text {th }}$ century trait leadership again emerged and provided much clearer understanding of process $[14,15]$.

Servant leadership is comparatively new dimension in the world of leadership theories and understandings. Concept of servant leadership was basically initiated by Robert and Spears in modern organizational theories. In the opinion of Greenleaf's [16] leader must be aware and keen enough to understand and accept the primary needs of his/ her workforce. The focus of this new dimension of leadership is on others (employees and workers) instead of leader himself/herself and consider oneself as servant for good and support [16] personal gain and interest must not motivate one for work or initiation of work or motivation rather then it should be for mutual benefit and interests [16-19]. "The servant leader's primary objective is to serve and meet the needs of others, which optimally should be the prime motivation for leadership" [20,21]. As per McMinn [22] this leader use to develop his people and help them to succeed and flourish, provide vision, get trust and reliability of people who work for him and influence them in positive and progressive way [23].

\section{Emotional intelligence}

If we study the history of intelligence literature, emotional intelligence has been rooted in social intelligence [24], which is related to specifies, understand and evaluate with management of people and act in accordance with human relations. It is also found that Emotional Intelligence theory was derived in 1970's and 80's by the work of psychologists Howard Gardner, John Mayer and Peter Salove. The first use of the term Emotional Intelligence is refers to [25] then [26] in A Study of Emotion: Developing Emotional Intelligence, [27] also use the term Emotional Intelligence in his writing and [28] and [4]. During the last decades after the publication of breakthrough book Emotional Intelligence of [29-31], after that successful publication he also write "examining emotional intelligence at work" [32] \& "Primal Leadership: Unleashing the Power of Emotional Intelligence [33]. Which also gives great popularity to the topic. Number of scholarly writings and articles has been published on the issue and its outcomes with respect to different fields and become a red hot topic for the writers of leadership and psychology.

Brackett et al. [34] said that emotional intelligence plays its role in workplace and influence the output and elements associated with work life but off course it is not a substitute of experience, knowledge and ability for leaders. It is linked with number of behaviors and variables associated and compatible in work environment [35-37].

Researchers proposed that $[29,30,38]$ dimensions of emotional intelligence on work setting along with leadership are "self-awareness, self-motivation, self-management, social awareness and relationship management" while in this study we will use trait theory of emotional intelligence. Konstantin Vasily Petrides (Soviet-born British psychologist) proposed a conceptual difference between trait model and ability based models of emotional intelligence and has been developing this model over many years in number of scientific publications.

Both academic and professional researchers and practitioners took interest in emotional intelligence and it has become a most current and up-to-date area in psychology and organizational psychological researches [39] with the passage of time emotional intelligence and organizational selection, training and development decisions became interlinked and associated [40-42]. On the other hand there are researchers who do not want to rely on this construct and are not in great favor [43], many others suggested that emotional intelligence is a useful predictor of leadership and job performance [44,45]. For instance, [46] wrote, "Emotional intelligence is much more powerful than IQ in determining who emerges as a leader. IQ is a threshold. You need it, but it doesn't make you a star. Emotional intelligence can." [47] said that emotion, feeling, intuition are consider as fundamental elements of leadership process which makes leadership more effective and dominant, and argued that "leadership is simply a function of emotion management".

\section{Emotional intelligence and leadership}

Organizations throughout the globe acknowledge the role of leadership and emotional intelligence also adhere that they play an important role in job performance of employees as well as physical and psychological well-being. Valid and workable interventions are required in organizations to assist workforce to perform their work optimally and effectively, relationships between servant leadership, emotional intelligence and effect of gender moderation suggestions for such interventions to put forward. This study is an attempt to put emphasis on emotional intelligence in workplace with leadership and it's interrelation with the dimensions of people orientation success.

Goleman [32] says that Emotional intelligence has a relationship with leadership and according to him individuals improve their emotional intelligence for the better outcomes at work. In the field of leadership and management, emotional intelligence is comparatively a modern concept. Number of studies has been conducted on the relationship of these variables and existence of strong relationship between them has been confirmed numerically. Emotional intelligence has now established its position in the fields of human resource, capital 
resource, labor union and organizational behaviors in almost all the type of organizations [30].

At the beginning of leadership literature emergence, it was considered that leadership is associated with military figures or physically strong and prominent personality who have built-in charisma. Even in this modern times people still use leadership associated with bold, brave and tough people with strong and rough personality. Whereas it doesn't fit with the new needs of today's corporate world like now-a-days workforce do not accept autocratic leadership or forced motivational factors. Leaders have to work with growing atmosphere of democratic and pen work life, employees have more choices, options, rights and interests in workplace then people working previously.

It is a process of social interaction in which ability of leaders behavior and relationship with followers can directly influence and enhance the outcome $[48,49]$. Humphery et al. [48] define leadership as "Leadership is an emotional process, whereby leaders recognize followers' emotional states, attempt to evoke emotions in followers, and then seek to manage followers' emotional states accordingly".

Wolff et al. [50] argue that by creating experience that is both shared and emotional at the same time, leader enhances group's solidarity and moral, and this ability of leader to change and control with influencing the emotion of followers can easily increase or decrease work performance [48]. Individual's ability to be socially influential and effective is an important factor of emotional intelligence $[35,51,52]$ and is viewed as basic indicator of effective leadership. George [51] aid that a leader who is emotionally intelligent can enhance efficiency and effectiveness at any level in organizational settings, while it also plays important role in interaction between workforce themselves [11]. Mayer et al. [51] hypothesized that employees with high level of emotional intelligence can easily coordinate and work with other employees and increase performance level. Mayer et al. [53] found out that individual who are high in emotional intelligence are able to understand and evaluate others' and their own emotions effectively and thus able to respond more flexibly in social and workplace interactions whereas [35] proposed leaders with higher emotional intelligence level are better at understanding work group members and can take actions to motivate them.

Among the current theories of leadership, servant leadership is one of the most updated and research requiring theory however it is still debatable that to what extent it is effective in organizational environment. Many researchers claim that servant leader is so concerned with needs and emotions of employees and workers that goals and needs of organization suffer as a result but in spite of this servant leadership place on a high rank in all theories of leadership, as it places a strong focus on followers need than any other previously presented theory. AS it is a responsibility of a leader to get work done in most effective and efficient way in which employees felt empowered and trusted with all work done at the same time, emotional intelligence plays a crucial and integral role. Thus Goleman pointed out that higher the level of hierarchy in organization higher will be the need of emotional intelligence and lower requirements of classical and traditional way of getting work done - in simple words there is direct relationship present between person's emotional intelligence and smarter work performance

Emotional intelligence produce great change in organizational effectiveness and employee's performance where there is leadership present. There are number of theories on leadership, developed with the passage of time. Among all of them, in this study we will use Servant Leadership to know the Emotional Intelligence effect on it which is comparatively a new leadership domain.

Specifically, this study seek to address the following questions regarding Emotional Intelligence and leadership:

- How much servant leadership can be predicted by Emotional intelligence in telecom sector of Pakistan?

- Does People Orientation of Servant Leaders changes by changing Emotional Intelligence of leaders?

- Does effect of Emotional Intelligence on servant leadership varies between genders?

There has been number of studies performed to explore about Emotional intelligence and leadership in varying contexts [8,54-63] which has given the insight and detail view of relationship in varying situations and context on utility, effectiveness and value of emotional intelligence and leadership

To find out the relationship of emotional intelligence with new emerged form of leadership i.e., servant leadership this is expected to be right time. This research will find out the exact relationship between the chosen variable and dimensions of people orientation of servant leadership, will be guided by theory-driven studies in both the emotional intelligence and leadership fields [58].

\section{Hypothesis}

H1: There is positive and significant relationship between Emotional Intelligence and Servant leadership.

H2: Genders respond differently toward Emotional Intelligence so does their relationship with servant leadership when effect by Emotional Intelligence.

\section{Theoretical framework}

Effect of emotional intelligence on servant leadership is shown in Figure 1.

\section{Research Design}

Both survey and statistical modelling methodologies were employed to guide the investigation. Standardized questionnaires is used to measure the two different constructs, based on the responses of 50 employees on a composite questionnaire.

The data in this study was analyzed by means of quantitative techniques. Primary data were collected through standardized questionnaires. The self-administered survey was the method employed in this study. Although survey studies provide a broad overview of the phenomenon being studied, they lack the ability to evaluate the theoretical models developed through a literature review. To overcome this limitation, statistical modelling was combined with the survey study to validate the theoretical model.

The research data were gathered in five separate private sector organizations within Pakistan. Almost of these organizations was located in the urban areas of country. The sample consisted of $34 \%$ female respondents and $66 \%$ male respondents. The education breakdown indicates that most respondents $(52 \%)$ had 18 years or more qualification or equivalent, followed by $44 \%$ with 16 years and $4 \%$ possesses 14 years of education. $72 \%$ respondents belongs to $(21-$ 30 ) years of age bracket while $16 \%$ belongs to $31-40$ years and only $12 \%$ are of $41-50$ years of bracket. In responses $74 \%$ were first line manager, 


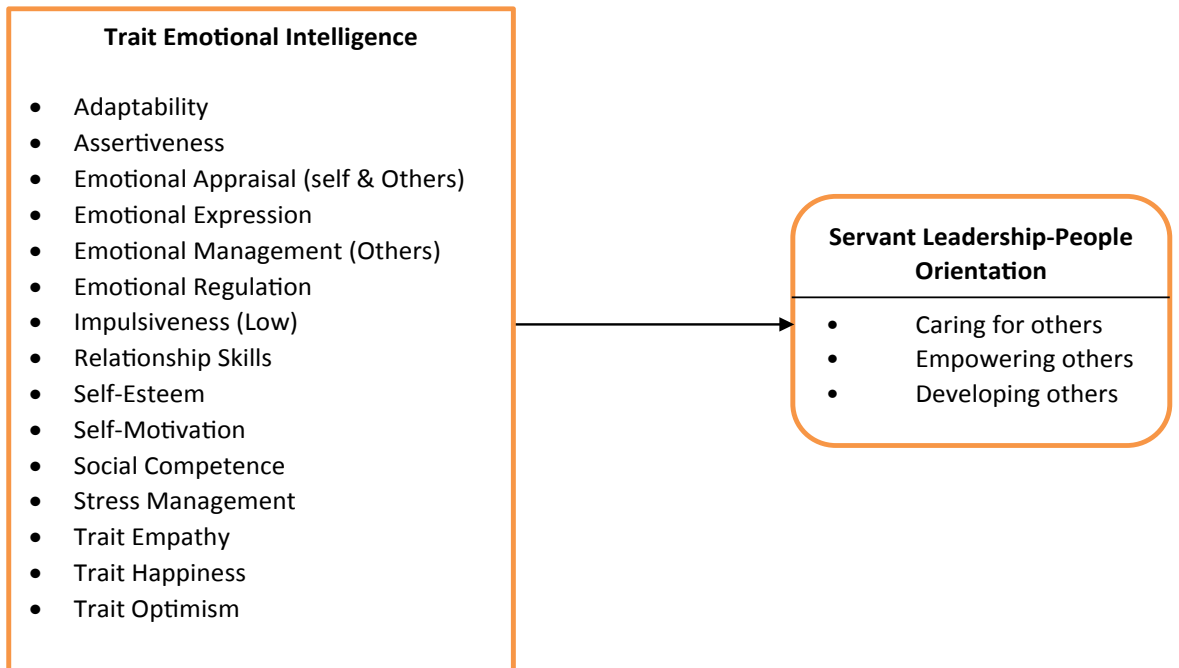

Figure 1: Effect of emotional intelligence on servant leadership.

\begin{tabular}{|c|c|c|c|c|}
\hline \multicolumn{5}{|c|}{ Correlations } \\
\hline & Trait Emotional Intelligence & Caring For Others & Empowering Others & Developing Others \\
\hline Trait Emotional Intelligence & 1 & & & \\
\hline Caring For Others & $.654^{* *}$ & 1 & & \\
\hline Empowering Others & $.637^{* *}$ & $.699^{* *}$ & 1 & \\
\hline Developing Others & $.414^{* *}$ & $.673^{* *}$ & $.844^{* *}$ & 1 \\
\hline
\end{tabular}

Table 1: Emotional intelligence separately effect each dimension of people orientation of servant leadership.

$20 \%$ were middle and $6 \%$ were top managers. The reporting period to current manager reflects a mean period of two years. Of the respondents, $65 \%$ have been reporting to their current manager for one year or less. After distributing 80 questionnaires to the population, a total of 50 candidates with usable responses were included in the sample. This represented a $62.5 \%$ response rate. Sample was representative of the population in which the questionnaires were used.

\section{Measuring instruments}

Two questionnaires were identified through the literature review as being reliable, valid and applicable to this study. A general discussion of each questionnaire's properties in terms of content, structure and psychometric features, as presented in the literature, follows.

Servant leadership [64] created the earliest servant leadership survey, the Self-Assessment of Servant Leadership Profile (SASLP). Page and Wong's goal was to develop a valid and reliable measure of servant leadership. Page and Wong developed a conceptual framework for assessing servant leadership. In this paper we are using only people orientation which includes caring for others, empowering others and developing others, which consist total of 20 items. 8 items for caring others, 5 items for empowering others and 7 items for developing others. Reliability and validity is satisfactory for all three dimensions.

For emotional Intelligence, Trait Emotional Intelligence Questionnaire-Short Form (TEIQue-SF; [65] will be used for getting data. 30 item questionnaire employed as a measure of trait theory. Two items for each 15 subscales, based primarily on their correlations with the corresponding total subscale scores. Items were responded to on 5 -point likert scale. The internal consistencies were satisfactory for both males and females (male 5.84, female 5.89).

\section{Results}

A high level of reliability was found for all the measurement scales utilized. The results of the structural equation model indicated that emotional intelligence in the manager affected people orientation of servant leadership and also suggest that gender plays vital role in understanding of interrelation.

There is high level of internal consistency for our scale used with this specific sample having 0.871 as value of Cronbach's $\alpha$. Means value of trait emotional intelligence calculated is 3.416 (S.D. 0.30269) and mean of servant leadership is 3.77 with S.D. of 0.477 . We are using Pearson correlation between variables as all are calculated using Likert scale of 5 points. There is positive and significant relationship present between two variables, which is significant at $1 \%$ level of confidence. Which depict that servant leadership going to change up to $63.2 \%$ in positive direction if emotional intelligence increase and vice versa.

Table 1 shows that emotional intelligence separately effect each dimension of people orientation of servant leadership. As table shows that trait leadership has positive and significant effect on caring for other dimension of leadership that is $65.4 \%$ while value is $63.7 \%$ for empowering others and $41.4 \%$ for developing others with level of significance is 0.01 .

$\mathrm{R}$ value of servant leadership is 0.632 and adjusted $\mathrm{R}$ square $=0.399$. Which implies $39.9 \%$ variability in people orientation of servant leadership can be accounted for trait theory of emotional intelligence.

An increase in one unit of emotional intelligence can increase servant leadership by 0.99 units only, and if there is not unit of 
Citation: Shamshad I (2016) Impact of Emotional Intelligence on People Orientation of Servant Leaders: Capacitive Study of Gender an Evidence from Telecom Sector of Pakistan. J Glob Econ 4: 228. doi: 10.4172/2375-4389.1000228

Page 5 of 7

emotional intelligence there is still 0.373 units of leadership exits, even without any emotional intelligence.

Servant Leadership $=0.373+0.99$ (Emotional Intelligence).

Effect of emotional intelligence level of each gender on specific dimension of people orientation for servant leadership is also appear as different for male and female. As shown in Table 2.

Mentioned Figure 2 is depicting that emotional intelligence of male effect negatively on caring for others i.e. $-10 \%$. Whereas effect on developing others and empowering others is $5 \%$ and $15 \%$ respectively.

Figure 3 showing that emotional intelligence of female has positive impact on all three facets that is $37 \%$ for caring for others, $46 \%$ developing others and 39\% empowering others.

\section{Discussion and Conclusion}

Leadership is present in every field of life whether it is corporation or multinational, educational or economic or financial institute, so emotional intelligence of individuals with their abilities to work

\begin{tabular}{|l|l|l|l|l|l|}
\hline & Female & \multicolumn{3}{l|}{ Male } & \\
\hline & Estimate & $\mathbf{P}$ & Estimate & $\mathbf{P}$ & z-stat \\
\hline Caring For Other & 0.373 & 0.002 & -0.096 & 0.532 & $2.384^{* *}$ \\
\hline Developing Others & 0.462 & 0.000 & 0.048 & 0.722 & $2.703^{* * *}$ \\
\hline Empowering Others & 0.394 & 0.000 & 0.146 & 0.371 & 1.371 \\
\hline Notes: ${ }^{* * *}$ p-value $<0.01 ;{ }^{* *} p$-value $<0.05 ;{ }^{*}$ p-value <0.10 \\
\hline
\end{tabular}

Table 2: Comparison of Male vs Female. individually or in team or lead a team. Finding out the relationship between servant leadership and emotional intelligence, our study add knowledge to current literature of servant leadership (specially) and emotional intelligence and effect of difference between genders on these variable relationship. First to the best of our understanding our study is one of few researches currently done in this area of finding the effect of Emotional Intelligence on people dimensions of servant leadership specifically. Secondly our study endorse that trait leadership has significant effect on servant leadership as whole which is theoretically proved by many scholars and gurus of the field $[66,67]$. Third, study result clearly showing that female are more of emotional as compare to men and have more impact on servant leadership dimensions. A possible and more supportive argument here is that females are emotionally more sensitive and aware and are tend to be more inclined toward the variable as compare to men and also possesses the tendency to show it and express more prominently $[67,68]$. This study results shows that approximately $40 \%$ variation in servant leadership can be achieved by suing emotional intelligence. Other results show that overall equation of impact of emotional intelligence on servant leadership is positively associated, linear and showing clear effect of variables on each other.

Coming studies are recommended to use different sectors like public sector or other industries of private sector. Remaining dimension of servant leadership with different theories of emotional intelligence will be serve a good research objective plus other demographical variable like age, culture could be used as mediator or moderator to test further

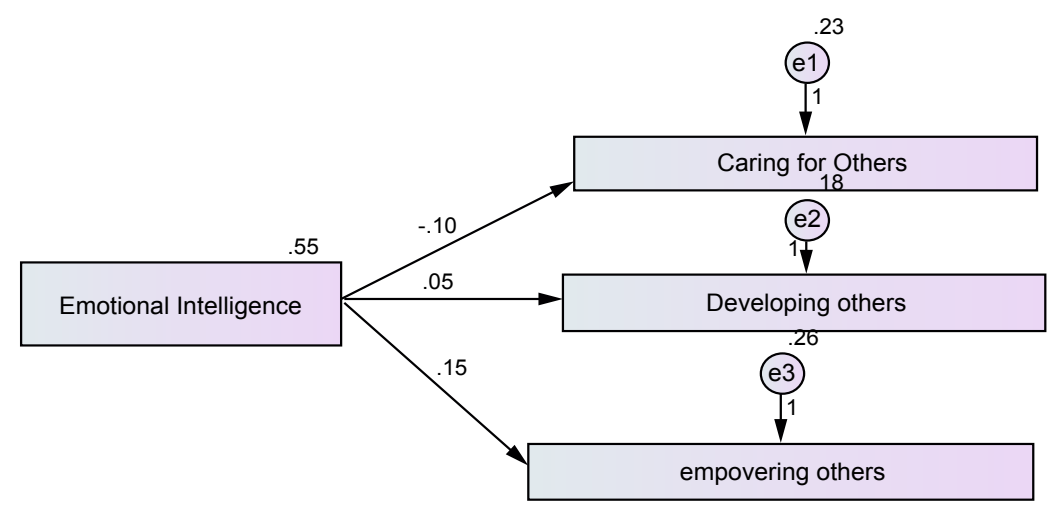

Figure 2: Model for Male.

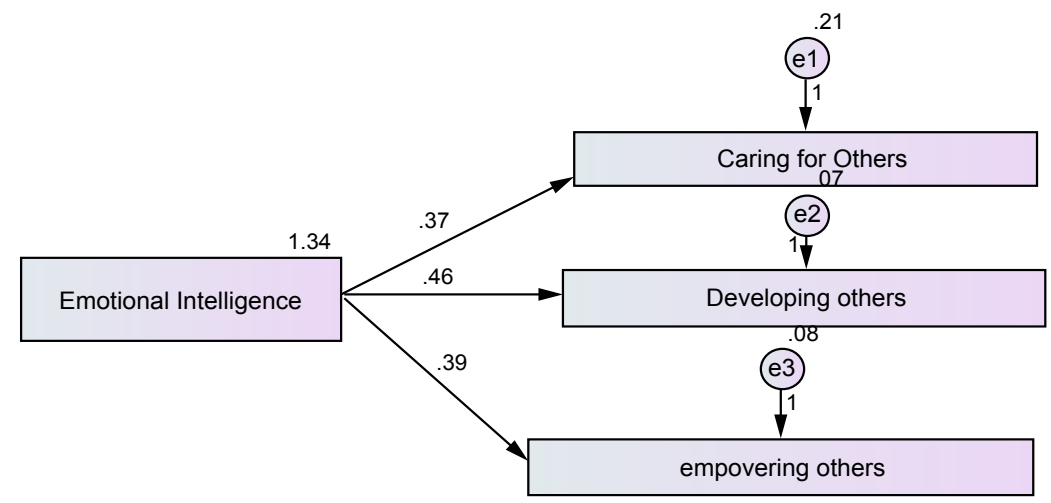

Figure 3: Model for Female. 
Citation: Shamshad I (2016) Impact of Emotional Intelligence on People Orientation of Servant Leaders: Capacitive Study of Gender an Evidence from Telecom Sector of Pakistan. J Glob Econ 4: 228. doi: 10.4172/2375-4389.1000228

Page 6 of 7

depth of area. Researches can conduct longitudinal research by using same variable after and before giving training in independent variable to check impact on dependent one.

\section{References}

1. Shatali D (2011) Effect of emotional intelligence on leadership behavior: a case study on UNRWA-Gaza health centers. Islamic University-Gaza Dean of Postgraduate Studies.

2. Fetzer J (2005) Leadership. Analytical and Bioanalytical Chemistry 381: 1311-1312.

3. Washington R (2006) Individual differences in servant leadership: The roles of values and personality. Leadership \& Organization Development Journal 27: 700-716.

4. Salovey P, Mayer JJD (1990) Emotional Intelligence. Imagination, Cognition, and Personality 9: 185-211.

5. Gil-Olarte Marquez P, Palomera Martin R, Brackett M (2006) Relating emotional intelligence to social competence and academic achievement in high school students. Psicothema 18: 118-123.

6. Salovey P, Mayer JD, Caruso D (2002) The Positive Psychology of Emotional Intelligence. Handbook of Positive Psychology.

7. Bernard V, Thomas J (1990) Evidence that stock prices do not fully reflect the implications of current earnings for future earnings. Journal of Accounting and Economics 13: 305-340.

8. Antonakis J, Ashkanasy NM, Dasborough MT (2009) Does leadership need emotional intelligence? Leadership Quarterly 20: 247-261.

9. Fiedler F, Chemers M (1967)A theory of leadership effectiveness. Administrative Science Quarterly 13: 344-348.

10. Graen G, Uhl-Bien M (1995) Relationship-based approach to leadership: Development of leader-member exchange (LMX) theory of leadership over 25 years: Applying a multi-level multi-domain. Leadership Quarterly 6: 219-247.

11. House R, Aditya R (1997) The social scientific study of leadership: Quo vadis? Journal of Management 3: 409-473.

12. Boring E (1950) Great men and scientific progress. Proceedings of the American Philosophical Society.

13. Terman L (1904) A preliminary study in the psychology and pedagogy of leadership. The Pedagogical Seminary 4: 413-483.

14. House R, Spangler W, Woycke J (1991) Personality and charisma in the US presidency: A psychological theory of leader effectiveness. Administrative Science Quarterly 36: 364-396.

15. Judge T, Bono J, llies R, Gerhardt M (2002) Personality and leadership: a qualitative and quantitative review. Journal of Applied Psychology 4: 765-780.

16. Greenleaf R (1977) Servant leadership.

17. Covey SR (2006) Servant Leadership. Leadership Excellence 23: 5-6.

18. Greenleaf $R$, Spears $L$ (2002) Servant leadership: A journey into the nature of legitimate power and greatness.

19. Pollard C (2000) The soul of the firm.

20. Russell R, Stone AG (2002) A review of servant leadership attributes: Developing a practical model. Leadership \& Organization Development Journal 23: $145-157$.

21. Stone AG, Russell RF, Patterson K (2004) Transformational versus servant leadership: A difference in leader focus. Leadership \& Organization Development Journal 25: 349-361.

22. McMinn T (2001) The conceptualization and perception of biblical servant leadership in the southern Baptist convention.

23. Farling M, Stone A, Winston B (1999) Servant leadership: Setting the stage for empirical research. Journal of Leadership Studies.

24. Thorndike E (1920) Intelligence and its uses. Harper's Magazine.

25. Leuner B (1966) Emotional intelligence and emancipation. A psychodynamic study on women. Praxis der Kinderpsychologie und Kinderpsychiatrie 15 196-203.
26. Payne W (1985) A study of emotion: developing emotional intelligence; selfintegration; relating to fear, pain and desire.

27. Greenspan S (1989) The development of the ego: Implications for personality theory, psychopathology, and the psychotherapeutic process.

28. Mayer J, DiPaolo M, Salovey P (1990) Perceiving affective content in ambiguous visual stimuli: A component of emotional intelligence. Journal of Personality Assessment 54: 772-781.

29. Goleman D (1995a) Emotional Intelegence.

30. Goleman D (1995b) Emotional intelligence: Why it can matter more that IQ.

31. Lunenburg FC (2011) Emotional Intelligence in the Workplace : Application to Leadership. International Journal of Management, Business, and Administration 14: 1-6.

32. Goleman D (1998) Working with emotional intelligence

33. Goleman D, Boyatzis R, McKee A (2013) Primal leadership: Unleashing the power of emotional intelligence.

34. Brackett M, Mayer J (2003) Convergent, discriminant, and incremental validity of competing measures of emotional intelligence. Pers Soc Psychol Bull 29 1147-1158.

35. Mayer JD, Salovey P, Caruso DR, Sitarenios G (2001) Emotional intelligence as a standard intelligence. Emotion 1: 232-242.

36. Trinidad D, Johnson C (2002) The association between emotional intelligence and early adolescent tobacco and alcohol use. Personality and Individual Differences 32: 95-105.

37. Vorbach A (2002) The relationship between emotional competence and social competence among early adolescents.

38. Cherniss C (2001) Emotional intelligence and organizational effectiveness.

39. Whitman D (2009) Emotional intelligence and leadership in organizations: A meta-analytic test of process mechanisms.

40. Bar-On R (1997) The Emotional Quotient Inventory (EQ-i): A test of emotional intelligence.

41. Law KKS, Wong CSC, Song LJL (2004) The construct and criterion validity of emotional intelligence and its potential utility for management studies. Journal of Applied Psychology 89: 483-496.

42. Salovey P (1997) Emotional development and emotional intelligence: Educational implications.

43. Landy $F$ (2005) Some historical and scientific issues related to research on emotional intelligence. Journal of Organizational Behavior 26: 411-424.

44. Rooy DV, Viswesvaran C (2004) Emotional intelligence: A meta-analytic investigation of predictive validity and nomological net. Journal of Vocational Behavior 65: 71-95.

45. Wong C, Law K (2002) The effects of leader and follower emotional intelligence on performance and attitude: An exploratory study. The Leadership Quarterly 13: $243-274$.

46. Bennis W (1994) On becoming a leader.

47. Stone AG (2004) Transformational versus servant leadership: A difference in leader focus. Leadership \& Organization Development Journal 25: 349-361.

48. Humphrey J, Schmitz H (2002) How does insertion in global value chains affect upgrading in industrial clusters? Regional Studies 36: 1017-1027.

49. Pirola-Merlo A, Hartel C, Mann L, Hirst G (2002) How leaders influence the impact of affective events on team climate and performance in R\&D teams. The Leadership Quarterly 13: 561-581.

50. Wolff S, Pescosolido A, Druskat V (2002) Emotional intelligence as the basis of leadership emergence in self-managing teams. The Leadership Quarterly 13: $505-522$

51. George JM (2000) Human Relations emotional intelligence. Human Relations 53: 1027-1055.

52. Petrides KV, Furnham A (2000) On the dimensional structure of emotional intelligence. Personality and Individual Differences 29: 313-320.

53. Mayer J, Caruso, D, Salovey P (1999) Emotional intelligence meets traditional standards for an intelligence. Intelligence 27: 267-298. 
Citation: Shamshad I (2016) Impact of Emotional Intelligence on People Orientation of Servant Leaders: Capacitive Study of Gender an Evidence from Telecom Sector of Pakistan. J Glob Econ 4: 228. doi: 10.4172/2375-4389.1000228

Page 7 of 7

54. Barling J, Slater F, Kelloway EK, Kerr R, Garvin J, et al. (2006) Transformational leadership and emotional intelligence: an exploratory study. Leadership \& Organization Development Journal 21: 157-161.

55. Butler CJ, Chinowsky PS (2006) Emotional Intelligence and Leadership Behavior in Construction Executives. Journal of Management in Engineering 22: 119-125.

56. Cook CR (2006) Effects of Emotional Intelligence on Principals' Leadership Performance.

57. Cote S, Lopes PNP, Salovey P, Miners CCTH (2010) Emotional intelligence and leadership emergence in small groups. The Leadership Quarterly 21: 496-508.

58. Du Plessis M, Wakelin Z, Nel P (2015) The influence of emotional intelligence and trust on servant leadership. SA Journal of Industrial Psychology 41: 1-9.

59. Fitzgerald S, Schutte NS (2010) Increasing transformational leadership through enhancing self-efficacy. Journal of Management Development 29: 495-505.

60. Harms PD, Crede M (2010) Emotional Intelligence and Transformational and Transactional Leadership: A Meta-Analysis. Journal of Leadership \& Organizational Studies 17: 5-17.

61. Leban W, Zulauf C (2004) Linking emotional intelligence abilities and transformational leadership styles. Leadership and Organization Development Journal 25: 554-564.
62. Sivanathan N, Cynthia Fekken G (2002) Emotional intelligence, moral reasoning and transformational leadership. Leadership and Organization Development Journal 23: 198-204.

63. Vivian Tang $H$, Yin M, Nelson DB (2010) The relationship between emotional intelligence and leadership practices. Journal of Managerial Psychology 25: 899-926.

64. Page D, Wong T (2000) A conceptual framework for measuring servantleadership. The Human Factor in Shaping the Course of History and Development.

65. Petrides KK, Frederickson N, Furnham A (2004) The role of trait emotional intelligence in academic performance and deviant behavior at school. Personality and Individual 36: 277-293.

66. Petrides K (2010) Trait emotional intelligence theory. Industrial and Organizational Psychology.

67. Petrides KV, Furnham A (2006) The role of trait emotional intelligence in a gender-specific model of organizational variables. Journal of Applied Social Psychology 36: 552-569.

68. Group IC (2003) Relationship between emotional intelligence and transformational leadership style: a gender comparison barbara mandell. Journal of Business and Psychology 17: 387-404. 